\title{
Dietary antioxidants and magnesium in type 1 brittle asthma: a case control study
}

\author{
J C Baker, W S Tunnicliffe, R C Duncanson, J G Ayres
}

\begin{abstract}
Background-Type 1 brittle asthma is a rare form of asthma. Atopy, psychosocial factors and diet may contribute to this condition. As increased dietary magnesium has a beneficial effect on lung function and selenium, vitamins $A, C$ and $E$ have antioxidant properties, a study was undertaken to test the hypothesis that patients with brittle asthma have diets deficient in these nutrients compared with subjects with non-brittle asthma and healthy adults. Methods-A case control study of the dietary intakes of 20 subjects with brittle asthma, 20 with non-brittle asthma, and 20 healthy adults was performed using five day weighed dietary records. Intake of magnesium was the primary outcome measure with selenium and vitamins $A, C$ and $E$ as secondary outcomes. Serum levels were measured at the same time as the dietary assessment.
\end{abstract}

Results-Sixty subjects ( 27 men) of mean age 49.5 years were recruited and completed the study. Subjects with brittle asthma had statistically lower median dietary intakes of vitamins $A$ and $E$ than the other groups (vitamin A: brittle asthma $522.5 \mu \mathrm{g} / \mathrm{day}$, non-brittle asthma $869.5 \mu \mathrm{g} /$ day, healthy adults $806.5 \mu \mathrm{g} / \mathrm{day}$; vitamin E: brittle asthma $4.3 \mathrm{mg} / \mathrm{day}$, non-brittle asthma $4.6 \mathrm{mg} / \mathrm{day}$, healthy adults $4.5 \mathrm{mg} /$ day). Median dietary intakes for the other nutrients were not significantly different between groups. Serum levels were within normal ranges for each nutrient in all subjects. Intakes less than the reference nutrient intake (RNI) for magnesium and vitamins $A$ and $C$, and less than the safe intake (SI) for vitamin $E$ were more likely in patients with brittle asthma than in those with non-brittle asthma.

Conclusion-Nutrient deficiency and reduced antioxidant activity may contribute to disease activity in type 1 brittle asthma, although a prospective study of replacement therapy will be needed to confirm this hypothesis.

(Thorax 1999;54:115-118)

Keywords: brittle asthma; dietary deficiency; magnesium; selenium; vitamins

Correspondence to: Mrs J C Baker.

Received 25 November 1997 Returned to authors 10 February 1998

Revised manuscript received

14 October 1998

Accepted for publication

16 October 1998
Brittle asthma ${ }^{1}$ is a rare form of severe asthma characterised by repeated life threatening attacks either on a background of wide variation in airflow (type 1 ) or on a background of apparent good control (type 2) despite sub- stantial medical treatment. ${ }^{2}$ Patients with brittle asthma have an increased risk of death and high morbidity ${ }^{3}$ and have been identified by the UK Asthma Task Force as a group in need of further study. ${ }^{4}$ A register of patients with brittle asthma in the West Midlands has been established with the intention of performing prospective studies of their outcome determinants. The reasons for "brittleness" are not known although atopy" and psychosocial factors ${ }^{6}{ }^{7}$ have both been shown to be associated with type 1 brittle asthma. We have recognised that these patients may eat a very restricted and often bizarre diet which appears to be a deliberate attempt to avoid both putative dietary allergens and excessive weight gain resulting from the use of oral steroids.

The potential role of diet in respiratory disease has been recognised ${ }^{89}$ and emerging evidence suggests that an association may exist between the deficient intake of certain nutrients and lung disease. ${ }^{10}$ Increased dietary magnesium has been shown to be associated with an independent beneficial effect on lung function, airway responsiveness, and wheezing in the UK population. ${ }^{11}$ Selenium is an essential component of glutathione peroxidase, an enzyme that helps to protect cells from oxidant damage. ${ }^{12}$ It has been hypothesised that selenium deficiency, acting through lowered activity of glutathione peroxidase, may have a role in the pathogenesis of asthma. ${ }^{13}{ }^{14}$ Deficiency of the antioxidant vitamins $\mathrm{A}, \mathrm{C}$ and $\mathrm{E}$ may also be important in the pathogenesis of asthma. A cross sectional survey of adults in Nottinghamshire, UK suggested that values of forced expiratory volume in one second $\left(\mathrm{FEV}_{1}\right)$ are directly related to the habitual intake of vitamin $C,{ }^{15}$ while an American study has suggested that a high intake of vitamin $\mathrm{C}$ is associated with reduced respiratory symptoms. ${ }^{16}$ Dietary vitamin A levels have been shown to be inversely associated with airway obstruction ${ }^{17}$ and an increased risk of airflow obstruction five years later. ${ }^{18}$ In a study of a group of UK elderly subjects, dietary intake of vitamin $\mathrm{E}$ was positively correlated with lung function; for every extra milligram increase in vitamin $\mathrm{E}$ in the daily diet, $\mathrm{FEV}_{1}$ increased by an estimated mean of $42 \mathrm{ml}$ and forced vital capacity (FVC) by an estimated mean of $54 \mathrm{ml}^{19}$

We undertook a pilot study of the dietary intake of eight women with type 1 brittle asthma using five day weighed dietary intakes. ${ }^{20}$ Every subject's intake of magnesium and selenium was below the reference nutrient intake (RNI), while some subjects' intake of vitamin A or $\mathrm{E}$ fell below the relevant levels. These preliminary data suggested that patients with 
brittle asthma may have diets deficient in nutrients important for respiratory health compared with patients with non-brittle asthma, and we have now tested this hypothesis in a larger case control study.

\section{Methods}

Permission for the study was obtained from the Research and Ethics Committee, East Birmingham Health Authority.

\section{STUDY DESIGN}

A case control study of the dietary intakes of subjects with brittle asthma, non-brittle asthma, and healthy adults using five day weighed dietary intakes was undertaken. Serum levels of the nutrients under study were measured in all subjects.

\section{SUBJECTS}

Twenty subjects with type 1 brittle asthma $(>40 \%$ diurnal variation in peak expiratory flow (PEF) for $50 \%$ of days over a period of 150 days despite treatment with an inhaled steroid in a dose of $>1500 \mu \mathrm{g} /$ day) from the West Midlands register were studied. Three subjects with brittle asthma had taken part in the pilot study but none of the subjects was aware of the nutrients being assessed. Twenty patients without brittle asthma matched for age, sex and inhaled steroid dose were identified from Birmingham Heartlands Hospital respiratory outpatient clinic. A healthy non-asthmatic "buddy control" matched for age and sex was identified by each subject with brittle asthma to comprise the other comparator group.

SAMPLE SIZE

The difference in mean daily magnesium intake was the primary outcome measure. Assuming 20 subjects in each group, and using a population standard deviation of daily magnesium intake of $46 \mathrm{mg}$ (determined in our pilot study), the study had $80 \%$ power at the $5 \%$ significance level to detect a difference in mean daily magnesium intake between groups of at least $40 \mathrm{mg}$.

DATA COLLECTION AND ANALYSIS

Using standard methodology ${ }^{21}$ portable electronic scales and a specifically prepared booklet, subjects recorded their daily dietary intake for five days including a weekend day. Handling of the dietary data was by means of a personal computer equipped with WISP (Tinuviel Software, Warrington, UK), a commercially available software package designed to analyse weighed dietary intakes. Blood sampling was performed on day 1 of the dietary recording. Analysis of serum magnesium was by spectrophotometry, ${ }^{22}$ serum selenium by electrothermal atomisation atomic absorption spectrometry using palladium matrix modification and Zeeman background correction, ${ }^{23}$ and vitamins $\mathrm{A}, \mathrm{C}$ and $\mathrm{E}$ by high performance liquid chromatography. ${ }^{24} 25$

STATISTICAL ANALYSIS

Non-parametric statistics were used for the analyses. The median dietary intakes and serum concentrations of nutrients were compared using Kruskal-Wallis one way analysis of variance. The proportion of subjects in each group who had dietary intakes less than the RNI (less than the safe intake (SI) for selenium) were also compared using $\chi^{2}$ tests.

DIETARY REFERENCE VALUES

Dietary reference values (DRVs) ${ }^{26}$ are defined as follows:

Estimated Average Requirement (EAR): a notional mean requirement (assuming the distribution of requirements in a group of individuals is normally distributed).

Reference Nutrient Intake (RNI): 2 standard deviations (SD) above the EAR. Intakes above this amount will be adequate for most individuals.

Lower Reference Nutrient Intake (LRNI): 2 $\mathrm{SD}$ below the EAR. Intakes below this amount will almost certainly be inadequate for most individuals.

Safe Intake (SI): for some nutrients that are known to have important functions in humans there are insufficient reliable data on human requirements to set DRVs. On the grounds of prudence, however, "safe intakes" have been set. These are judged to be a level, or range of intake, at which there is no risk of deficiency and below a level where there is risk of undesirable effects.

\section{Results}

\section{SUBJECTS}

Twenty subjects (nine men) with brittle asthma of mean age 49.4 years taking inhaled steroids in a mean dose of $1875 \mu \mathrm{g} /$ day were recruited, along with 20 matched control subjects with non-brittle asthma of mean age 49.9 years taking inhaled steroids in a mean dose of $1542 \mu \mathrm{g} /$ day and 20 healthy non-asthmatic adults of mean age 49.3 years. One subject with brittle asthma smoked cigars (one per day), two with non-brittle asthma smoked cigarettes (both $15 /$ day), and four healthy adults smoked cigarettes (mean 18/day, range 15-20). All 60 subjects completed the protocol.

\section{MAGNESIUM}

There was a $44 \mathrm{mg}$ difference between the median intake values of subjects with brittle asthma and those with non-brittle asthma, and a $43 \mathrm{mg}$ difference between the median levels of subjects with brittle asthma and normal controls (table 1), but these differences did not achieve statistical significance. Serum levels for all subjects in each group were within the normal range (table 2), the median level being the same for each group.

SELENIUM

The median dietary intake (table 1 ) and serum level (table 2) was lowest in patients with brittle asthma but was not significantly different from subjects in the other two groups.

\section{VITAMIN A}

Dietary intakes of vitamin A were significantly lower in subjects with brittle asthma $(522.5 \mu \mathrm{g})$ than in those with non-brittle asthma 
Table 1 Median dietary intakes (with interquartile ranges) of nutrients in the three study groups

\begin{tabular}{llccc}
\hline Nutrient & RNI & Brittle asthma & Non-brittle asthma & Healthy adults \\
\hline $\mathrm{Mg}$ & $270 \mathrm{mg}$ /day & $233.0(174.0-275.0)$ & $277.0(206.5-323.5)$ & $276.0(214.0-312.0)$ \\
$\mathrm{Se}$ & $60 \mu \mathrm{g} /$ day & $42.0(35.0-49.0)$ & $52.0(34.5-63.5)$ & $50.0(33.5-74.0)$ \\
Vitamin A & $600 \mu \mathrm{g}$ /day & $522.5(270.0-798.0)$ & $869.5(667.5-1189.5)^{\star}$ & $706.5(580.0-987.5)^{\star \star}$ \\
Vitamin C & $40 \mathrm{mg}$ day & $48.0(29.0-89.5)$ & $64.0(49.0-101.5)$ & $81.5(50.0-128.5)$ \\
Vitamin E & $3 \mathrm{mg}$ /day (SI) & $3.4(2.0-3.9)$ & $4.6(3.3-6.3) \dagger$ & $4.5(3.0-6.4)+\dagger$ \\
\hline
\end{tabular}

$\mathrm{RNI}=$ reference nutrient intake; $\mathrm{SI}=$ safe intake. Brittle asthma:non-brittle asthma ${ }^{\star} \mathrm{p}=0.01$; brittle asthma:healthy adults ${ }_{\star \star *} \mathrm{p}=0.04$; brittle asthma:non-brittle asthma $\mathrm{tp}=0.005$; brittle asthma:healthy adults $+\mathrm{p}=0.007$.

Table 2 Median serum levels (with interquartile ranges) of nutrients in the three study groups

\begin{tabular}{llccc}
\hline Nutrient & Normal range & Brittle asthma & Non-brittle asthma & Healthy adults \\
\hline $\mathrm{Mg}$ & $0.6-1.0 \mathrm{mmol} / 1$ & $0.9(0.8-0.9)$ & $0.9(0.8-0.9)$ & $0.9(0.9-1.0)$ \\
$\mathrm{Se}$ & $0.89-1.65 \mu \mathrm{mol} / 1$ & $1.0(0.8-1.2)$ & $1.0(1.0-1.2)$ & $1.1(1.0-1.2)$ \\
Vitamin A & $0.7-1.5 \mu \mathrm{mol} / 1$ & $2.8(2.2-3.2)$ & $2.7(2.3-3.3)$ & $2.6(2.2-2.8)$ \\
Vitamin C & $26-86 \mu \mathrm{mol} / 1$ & $35.1(24.7-64.0)$ & $56.9(46.8-63.3)$ & $49.6(32.3-63.8)$ \\
Vitamin E & $11.5-24.4 \mu \mathrm{mol} / 1$ & $31.8(29.3-35.4)$ & $29.8(24.4-34.3)$ & $28.8(26.3-31.50)$ \\
\hline
\end{tabular}

Table 3 Number of individuals in the brittle and non-brittle asthma groups with dietary intakes $<R N I$ or $<S I$

\begin{tabular}{|c|c|c|c|c|c|}
\hline \multirow[b]{2}{*}{$\begin{array}{l}\text { Subject groups } \\
(n=20)\end{array}$} & \multicolumn{4}{|c|}{$<R N I$} & \multirow{2}{*}{$\begin{array}{l}<S I \\
\text { Vitamin }\end{array}$} \\
\hline & $M g$ & Se & $\begin{array}{l}\text { Vitamin } \\
A\end{array}$ & $\begin{array}{l}\text { Vitamin } \\
\text { - }\end{array}$ & \\
\hline Brittle asthma & $16^{\star}$ & 18 & $12 \dagger$ & $9 \ddagger$ & $12 \#$ \\
\hline $\begin{array}{l}\text { Non-brittle } \\
\text { asthma }\end{array}$ & $10^{\star}$ & 16 & $6 \dagger$ & $2 \ddagger$ & $5 \#$ \\
\hline Healthy adults & 12 & 15 & 9 & 4 & 6 \\
\hline
\end{tabular}

Magnesium, brittle asthma:non-brittle asthma ${ }^{*} \mathrm{p}=0.05$; Vitamin A, brittle asthma:non-brittle asthma $t p=0.06$; Vitamin C, brittle asthma:non-brittle asthma $\neq \mathrm{p}=0.01$; Vitamin $\mathrm{E}$, brittle asthma:non-brittle asthma $\# \mathrm{p}=0.03$.

$(869.5 \mu \mathrm{g})$ and healthy controls $(706 \mu \mathrm{g}) ; \mathrm{p}=$ 0.01 and 0.04 , respectively (table 1 ). Serum levels for all subjects exceeded the normal range (table 2).

VITAMIN C

The median dietary intake of vitamin $\mathrm{C}$ was lowest in subjects with brittle asthma but the difference was not statistically significant (table 1). Serum levels of vitamin $C$ were within the normal range for all subjects (table 2), but subjects with brittle asthma had the lowest median level $(35.1 \mu \mathrm{mol} / \mathrm{l})$ compared with $56.9 \mu \mathrm{mol} / 1$ in those with non-brittle asthma and $49.6 \mu \mathrm{mol} / 1$ in normal subjects, although the differences were not statistically significant.

VITAMIN E

Analysis of the daily dietary intake of vitamin E showed subjects with brittle asthma to have significantly lower median values of intake $(3.4 \mathrm{mg})$ than those with non-brittle asthma $(4.6 \mathrm{mg})$ and healthy adults $(4.5 \mathrm{mg}), \mathrm{p}=$ 0.007 (table 1). Serum levels of vitamin E exceeded the normal range for all subjects and were highest in subjects with brittle asthma (table 2).

PROPORTIONS OF SUBJECTS < RNI OR < SI

The proportion of subjects in each group whose dietary intakes were $<$ RNI $(<$ SI for vitamin E) was consistently higher in the subjects with brittle asthma than in those with nonbrittle asthma ( $p=0.05$ for magnesium, $p=$ 0.01 for vitamin $C, p=0.03$ for vitamin $E$, and $\mathrm{p}=0.06$ for vitamin $\mathrm{A}$; table 3 ).

\section{Discussion}

We have tested the hypothesis that patients with brittle asthma have diets deficient in magnesium, selenium, and vitamins $\mathrm{A}, \mathrm{C}$ and $\mathrm{E}$. We found that dietary intakes of magnesium, selenium, and vitamin $\mathrm{C}$ were lower in subjects with brittle asthma, but not significantly so, when compared with subjects with non-brittle asthma and normal subjects, but that intakes of vitamins $\mathrm{A}$ and $\mathrm{E}$ were significantly deficient when compared with subjects in the other two groups. There are, however, a number of methodological issues which need to be addressed when interpreting these findings.

The lack of statistical significance with respect to magnesium may have resulted from the study being underpowered. The population SD for magnesium which we found $(90.4 \mathrm{mg})$ is greater than the $46 \mathrm{mg}$ observed in the pilot study which was used for the power calculation, but similar to that reported in previous published work $(100 \mathrm{mg}) .{ }^{11}$ The study may therefore have been underpowered, resulting in a type 1 error. However, these patients are rare and are widely spread geographically, resulting in logistical difficulties in recruiting larger numbers.

Smoking habit was not adjusted for. Only $10 \%$ of the 60 subjects smoked cigarettes (none in the group with brittle asthma) and it is unlikely that smoking will have affected our results. Indeed, as the smokers were only represented in the two comparator groups an association of poor diet with smoking will, if anything, have underestimated the dietary deficiencies between brittle asthma and the other two groups.

The "gold standard" methodology for undertaking non-epidemiological dietary surveys is the seven day weighed dietary record. ${ }^{27}$ Patient fatigue is a recognised problem with this method. To avoid this we used five day weighed records, specifically including one weekend day (A E Black, personal communication). Dietary survey methods are validated against each other ${ }^{28}$ but not against habitual daily intake, and the problem of underreporting of energy intake is well documented. ${ }^{29}$ Since food sources of the nutrients studied are not energy dense (except for rarely eaten foods containing fish oils and fish liver oils), the data collected should not be 
affected by under-reporting. If under-reporting occurred in our study it would be expected to be across all groups and therefore is unlikely to be the sole explanation for the lower dietary intakes in subjects with brittle asthma compared with the other two groups. This is also true of the problem of inaccuracy of weighing and/or recording.

Whilst under-reporting may account for the miscorrelation of the dietary intakes and the biochemical analyses in our study, there are problems with the use of serum levels as an indication of dietary intake ${ }^{30}$ and reference ranges are contentious. For example, serum magnesium levels may not reflect dietary intake since the efficiency of magnesium absorption increases from $25 \%$ on high magnesium diets to $75 \%$ on magnesium restricted diets. ${ }^{31}$ When magnesium intake decreases the kidney conserves magnesium very efficiently, the skeleton acting as a store. Serum selenium levels are the most commonly used measure of selenium status but, as a general rule, they reflect dietary selenium intake only when the intake is subnormal. ${ }^{32}$ Serum levels of vitamin A are only sensitive to persistently low intakes of vitamin $\mathrm{A}$ and even then they do not fall until the liver stores are exhausted, plasma concentrations only falling below $0.7 \mu \mathrm{mol} / 1$ in the later stages of deficiency. Consequently, other measures of nutrient and vitamin status may be more helpful in studies-for example, glutathione peroxidase levels in erythrocytes for selenium status, in leucocytes for vitamin $\mathrm{C}$, in adipose tissue for vitamin $\mathrm{A}$ and the serum tocopherol:cholesterol ratio for vitamin $\mathrm{E}$. Nevertheless, we have found deficient intakes of vitamins $\mathrm{A}$ and $\mathrm{E}$ in brittle asthma, the reasons for which are not fully characterised.

However, it appears that the diets of patients with brittle asthma are compromised by perceived and/or real food intolerance which affects $65 \%$ of patients with brittle asthma (unreported data from our unit), and by a need to reduce kilocalorie intake because of weight gain resulting from the use of oral steroids. Such alterations in the diet would produce the pattern of deficiency seen in these patients. Nutrient deficiency and the resultant reduced antioxidant activity may thus enhance asthmatic inflammation, consequently contributing to bronchial hyperreactivity in this group of patients. It is also true that these patients have high levels of psychosocial morbidity, ${ }^{67}$ and one factor which might in part or in total explain these differences are inaccuracies in reporting their dietary intakes.

In conclusion, we have found that dietary records in our study support the hypothesis that intakes of vitamins $\mathrm{A}$ and $\mathrm{E}$ are deficient in patients with brittle asthma. This was not matched by serum levels but could be accounted for by under-reporting of dietary intake, inaccuracy in weighing and/or recording of dietary intake (serum levels not being the best measures of dietary intake), or by systematic differences in the handling of nutrients. On the basis of these findings it would seem reasonable to undertake a study of nutrient and vitamin supplementation to determine whether an increase in the intake of these nutrients will improve the respiratory health of patients with brittle asthma.

We are grateful to the Departments of Clinical Chemistry at Birmingham Heartlands Hospital and City Hospital, Birmingham and to the Dunn Nutrition Centre Laboratories, ham and to the Dunn Nutrition Centre Laboratories, selenium; and vitamin C assays respectively, and to A E Black of selenium; and vitamin C assays respective
the Dunn Nutrition Centre for advice.

1 Ayres JG. Classification and management of brittle asthma. Br f Hosp Med 1997;57:387-9.

2 O'Driscoll BRC, Ruffles SP, Ayres JG et al. Long term treatment of severe asthma with subcutaneous terbutaline. $\mathrm{Br} F$ Dis Chest 1988;82:360-7.

3 Westerman DE, Benatar SR, Potgeiter PD, et al. Identification of the high risk asthmatic patient. Am $\mathcal{F}$ Med 1979;66: 565-72.

4 UK National Asthma Task Force on Asthma. Summary document of the first meeting at the Royal College of Physicians, 2 July 1991.

5 Miles JF, Cayton RM, Ayres JG. Increased atopy in brittle compared to non-brittle asthma. Clin Exp Allergy 1994;49: 401-4.

6 Garden GMF, Ayres JG. Psychiatric and social aspects of brittle asthma. Thorax 1993;48:501-5.

7 Miles JF, Garden GMF, Tunnicliffe WS, et al. Psychological morbidity and coping skills in patients with brittle and morbidity and coping skills in patients with brittle and
non-brittle asthma:a case control study. Clin Exp Allergy

8 Sridhar MK. Nutrition and lung health. Should people at risk of chronic obstructive lung disease eat more fruit and vegetables? BMF 1995;310:75-6.

9 Strachan DP, Cox BD, Erzinclioglu SW, et al. Ventilatory unction and winter fresh fruit consumption in a random sample of British adults. Thorax 1991;46:624-9.

10 Soutar A, Seaton A, Brown K. Bronchial reactivity and dietary antioxidants. Thorax 1997;52:166-70.

11 Britton J, Pavord I, Richards K, et al. Dietary magnesium, lung function, wheezing and airway hyper-reactivity in a random adult sample. Lancet 1994;344:357-62.

12 Beasley R, Thomson CD, Pearce N. Selenium, glutathione peroxidase and asthma. Clin Exp Allergy 1991;21:157-9.

13 Flatt A, Pearce N, Thomson CD, et al. Reduced selenium in asthmatic subjects in New Zealand. Thorax 1990;45:95-9.

14 Hasselmark L, Malmgren R, Zetterstrom O, et al. Selenium supplementation in intrinsic asthma. Allergy 1993;48:30-6.

15 Britton J, Pavord I, Richards K, et al. The effects of dietary antioxidants on lung function in the general population. Am Rev Respir Dis 1993;147:369.

16 Schwartz J, Weiss SJ. Relationship between dietary vitamin $\mathrm{C}$ and pulmonary function in the first National Health and Nutrition Examination Survey (NHANES I). Am $\mathcal{f}$ Clin Nutr 1994;59:110-4.

17 Morabia A, Serenson A, Kumanyiki S, et al. Vitamin A, cigarette smoking and airway obstruction. Am Rev Respir Dis 1989;140:1312-6.

18 Morabia A, Menkes MJS, Comstock GW, et al. Serum retinol and airway obstruction. Am f Epidemiol 1990;132:77-82.

19 Dow L, Tracey M, Villar A, et al. Does dietary intake of vitamins C and E influence lung function in older people? $\mathrm{Am}$ mins C ar Crit Care Med 1996;154:1401-4.

20 Baker JC, Tunnicliffe WS, Duncanson RC, et al. Reduced dietary intakes of magnesium, selenium and vitamins A, C and $\mathrm{E}$ in patients with brittle asthma. Thorax 1995; 50(Suppl 2):P97.

21 Bingham SA. The dietary assessment of individuals: methods, accuracy, new techniques and recommendations. Nutr Abstr Rev 1987;57:705-42

22 Varley H. Practical chemistry. 5th edn, Volume 1, 863. London: Heinemann Medical, 1991.

23 Sheehan TMT, Halls DJ. The measurement of selenium in clinical specimens. Ann Clin Biochem (in press)

24 Thurnham DI, Smith E, Flora PS. Concurrent liquid chromatography assay of retinol, alpha-tochopherol, betacarotene, alpha-carotene, lycopene and beta-cryptoxanthin in plasma with tochopherol as internal standard. Clin Chem 1988;34:377-81.

25 Vuilleumier JP, Keck E. Fluorometric assay of vitamin C in biological materials using a centrifugal analyser with fiological materials using a centrifugal analyser with

26 Department of Health. Dietary reference values for food and nutrients for the United Kingdom. Report of the Panel on Dietary Reference Values of the Committee on Medical Aspects of Food Policy. London: HMSO, 1991.

27 Lessof MH. Food intolerance. London: Chapman and Hall, 1992: 42 .

28 Bingham SA, Gill C, Welch A, et al. Comparison of dietary assessment methods in nutritional epidemiology: weighed records, $24 \mathrm{~h}$ recalls, food frequency questionnaires and estimated diet records. Br F Nutr 1994;72:619-43.

29 Goldberg GR, Black AE, Jebb SA, et al. Critical evaluation of energy intake data using fundamental principles of energy physiology: 1 . Derivation of cut-off limits to identify under-recording. Eur f Clin Nutr 1991;45:569-81.

30 Kohlmeier L. Future of dietary exposure assessment. Am $\mathcal{f}$ Kohlmeier L. Future of dietary exp

1 Wester PO. Magnesium. Am f Clin Nutr 1987;45:1305-12.

31 Wester PO. Magnesium. Am f Clin Nutr 1987;45:1305-12. Neve J, Vertongen F, Molle L. Sel
Endocrinol Metab 1985;14:629-56. 